\title{
Serum 25-hydroxyvitamin D status and wheezing in pre-school children, Kuwait
}

\author{
Alaa Mohamed AbdelKader ${ }^{1-3}$ and May Fouad Nassar ${ }^{2,3}$ \\ ${ }^{1}$ Paediatric Department, Faculty of Medicine, Mansoura University, Dakahlia, Egypt. ${ }^{2}$ Paediatric Department, Faculty of Medicine, Ain Shams Univer- \\ sity, Cairo, Egypt. 3Paediatric Department, Al-Adan Hospital, Ministry of Health, Kuwait. (Correspondence to: May Fouad Nassar: maie_nassar@yahoo. \\ co.uk).
}

\begin{abstract}
Background: There has been growing recognition of the critical extra-skeletal roles for vitamin D including lung disease. Aims: This study was performed to explore the possible role of vitamin D on wheezing occurrence among Kuwaiti preschool children.

Methods: Out of 244 children from Al-Adan Hospital, Kuwait, 151 cases were enrolled as wheezers while the rest served as controls. The wheezers were subdivided into episodic wheezers (EW) and multiple trigger wheezers (MTW). Detailed history of the wheezing attacks, previous hospitalizations, and intensive care admission were recorded as well as their serum 25-hydroxyvitamin D [25(OH)D] levels.

Results: Serum 25(OH)D was significantly lower in the wheezing group, and its decrease was a risk factor for wheezing. Moreover, serum 25(OH)D was not significantly different between EW and MTW; nevertheless, its low level could be linked to MTW.

Conclusions: Vitamin D deficiency increases the risk of wheezing among preschoolers in Kuwait. A possible link between low serum 25(OH)D and MTW could highlight a specific role for vitamin D in relation to atopy. Prevention and prompt management of vitamin D deficiency should be considered among infants and children with wheezing.

Keywords: asthma, early wheezing, pre-school children, serum hydroxyvitamin D, Kuwait

Citation: AbdelKader AM; Nassar MF. Serum 25-hydroxyvitamin D status and wheezing in pre-school children, Kuwait. East Mediterr Health J. 2019;25(3):197-204 https://doi.org/10.26719/emhj.18.031

Received: 15/08/16; accepted: 03/10/17

Copyright (c) World Health Organization (WHO) 2019. Some rights reserved. This work is available under the CC BY-NC-SA 3.0 IGO license (https:// creativecommons.org/licenses/by-nc-sa/3.o/igo)
\end{abstract}

\section{Introduction}

Vitamin D, whether produced in the skin upon sun exposure or ingested from various dietary sources, is converted in the liver to 25 -hydroxyvitamin $\mathrm{D}[25(\mathrm{OH}) \mathrm{D}]$. The latter is the major circulating form of vitamin $\mathrm{D}$ and is thus used for evaluating the vitamin D status of patients $(1,2)$. The flesh of fatty fish (such as salmon, tuna, and mackerel) and fish liver oils are among the best sources of vitamin $\mathrm{D}$ and the fortified cereals and milk provide adequate amounts as well (3).

Countries of the Gulf region including Kuwait, have become increasingly modernized, resulting in a transformation of lifestyle based on technology, sedentary activity, lack of sunlight, and unhealthy dietary patterns. These factors have led to a higher prevalence of vitamin D undernutrition (4). The nutritional rickets is multifactorial but one of the most important contributors is insufficient intake of vitamin D (5), which has been reported in many age groups in Kuwait whether university women (6) or high school children (7). Additionally, a recent report describes the inadequacy of early vitamin $\mathrm{D}$ supplementation practice by physicians working in Kuwait (8). Regarding vitamin D status in Kuwait, Molla et al. (9) also reported that $40 \%$ of their studied mothers and $60 \%$ of the neonates were vitamin $\mathrm{D}$ deficient on the day of delivery. Recently, low vitamin
D status was still reported among adolescent females in Kuwait (98.7\% had a level below $50 \mathrm{nmol} / \mathrm{L})(10)$.

There has been growing recognition of the critical extra-skeletal roles for vitamin D in recent years (11) with an explosion of interest in vitamin D across health disciplines including lung disease (12). Recently, vitamin $D$ was found to be low in patients with recurrent wheezes (13); a problem which was reported to be moderately present among children in Kuwait (14). Recurrent wheeze in young children, either transient or that will continue as asthma, can be severe and cause significant impairment in quality of life, with frequent use of health care systems and great expense $(15,16)$. The aim of this study was to explore the possible impact of vitamin D status on occurrence of wheezing and its pattern among preschool children in Kuwait.

\section{Methods}

This cross-sectional study was performed in the outpatient clinics, Paediatric department, Al-Adan Hospital, Al-Ahmadi district, Kuwait, from 1 April 2013 to 31 August 2014. It included 244 Kuwaiti pre-school children (age 2 to 5 years) who presented at the outpatient clinic for vitamin D status evaluation, and were recruited after obtaining consents from the parents or care givers.

Full demographic and social data were collected 
from all enrolled subjects. Detailed history regarding previous wheezing episodes, if any, was taken from them. Wheezing status was assessed by asking the same questions to all parents/caregivers: was there wheezing or whistling sound in the chest at any time? Did the child ever need to use inhaled drugs through nebulizer or spacer to relieve cough? Wheezing sounds or difficult breathing? Was he/she ever diagnosed as a wheezer/ asthmatic by a doctor? The same questions were asked by one of the principle researchers for all parents or care givers in direct face-to-face interviews to minimize bias and assure strict inclusion and exclusion criteria enforcement.

The children were divided into two groups: the wheezing group that included cases with more than one wheezing attack in the last year, and their physicians confirmed them as wheezers; and the control group, which reported no previous history of wheezing. For the wheezing group, special emphasis was given to the number of wheezing attacks in the past year, number of emergency room (ER) visits, need for hospital admission or any paediatric intensive care (PICU) admission for wheezing, if any. Triggers of wheezing episodes and use of rescue and control medications were also recorded. Cases in the wheezing group were further subdivided into episodic wheezers (EW) and multiple trigger wheezers (MTW) according to Brand et al. (17). According to this classification, children were diagnosed as EW if they have intermittent wheezing episodes that are mostly associated with evidence of viral illness and cold and are well in between those attacks. However, wheezers are labeled as MTW if they have wheezes between the discrete episodes.

The timing of serum vitamin $\mathrm{D}$ assessment was recorded and seasonal variations in vitamin D levels were accounted for in the regression analysis. Other confounding variables that were collected included: parental smoking, consanguinity, family history of atopy, other atopies in the enrolled cases, daycare attendance, number of persons living in the same house, and number of children sleeping in the same bedroom. To ensure homogeneity among the studied cases, only Kuwaiti children were enrolled to avoid major cultural and social differences that might affect vitamin D levels or the diagnosis of wheezing. Since all cases presented with serum level for 25-hydroxy vitamin $D$, ethical research committee approval was waived.

Exclusion criteria included patients with chronic lung and congenital heart diseases as well as cases who received vitamin $\mathrm{D}$ supplementation in the 3 months prior to enrollment or had an acute illness at time of vitamin D assay. We also excluded cases without doctor diagnosed wheezing and with only one wheezing episode in the last year as reported by parents. Wheezers in the episodic group were excluded if they received control medications between attacks. Patients with body mass index (BMI) below 3rd percentile and those $\geq 8$ th percentile were excluded to avoid effect of disturbed nutritional status on vitamin D level and occurrence of wheezing. Additionally, ex-preterm cases and those with poor data recall were also excluded. Lastly patents/caregivers refusing to participate in the study were not included.

Finally, serum $25(\mathrm{OH}) \mathrm{D}$ was measured in a peripheral venous blood sample from each child by electrochemiluminesence assay (ECLA) using Cobas e602 autoanalyzer from Roche diagnostic Company in the AlAdan Hospital laboratory with a measuring range of 3.00 $70.00 \mathrm{ng} / \mathrm{mL}(7.50-175 \mathrm{nmol} / \mathrm{L})$. The serum samples were separated after 10 minutes of centrifugation. Samples were processed immediately for cases and controls under similar laboratory conditions. Laboratory staff were blinded to the case-control status of the samples. Interpretation of 25(OH)D levels was done according to the US Endocrine Society guideline (18), which defines vitamin D deficiency as $25(\mathrm{OH}) \mathrm{D}$ less than $20 \mathrm{ng} / \mathrm{ml}(50$ $\mathrm{nmol} / \mathrm{l})$, vitamin D insufficiency as $25(\mathrm{OH}) \mathrm{D}$ between 21 and $29 \mathrm{ng} / \mathrm{ml}$.

The sample size was calculated setting the confidence level at $95 \%$, the margin of error at 0.05 , and the power $(1-\beta)$ at 0.85 . According to the previous reports, vitamin $D$ deficiency is reported in around $40-50 \%$ of the population (9). For the wheezing group we assumed the deficiency could reach $65 \%$, and sample size was calculated to be 187 (at least 93 patients in each group).

IBM SPSS Statistical package for social science, version 20, was used for data analysis. Descriptive statistics were generated for demographic factors; chi-square test was used to compare categorical data. Continuous data were compared using Mann-Whiteny U test and Kruskal-Wallis test. For assessment of possible role between vitamin D status and wheeze we used the multivariate regression analysis. Data are presented as median (inter quartile ranges [IQR]) for continuous data and number and percentage for categorical data. $P<0.05$ is considered significant.

\section{Results}

Three hundred and thirty-one cases were initially screened; however, only 244 children were included in the study. The age range of the enrolled children was 24 to 69 months, and their median was 32 and IQR 28-40 months, and 134 (54.9\%) were females. One hundred and fifty-one children were included in the wheezing group and they were further divided into $96 \mathrm{EW}$ and 55 MTW (Figure 1).

Table 1 shows the demographic characters of the enrolled children and their vitamin D status. Significantly, more wheezers gave positive history of other atopies and parental smoking with higher person to bedroom ratio. Children in the wheezing group had significantly lower serum $25(\mathrm{OH}) \mathrm{D}$ level when compared to the control group $(P<0.001)$.

Table 2 compares the EW to the MTW regarding socio-demographic data, $25(\mathrm{OH}) \mathrm{D}$ levels, ER visits, and the need for hospital admission. More MTW gave positive history of parental smoking $(P=0.042)$, person to bedroom ratio $(P=0.046)$, and $E R$ visits in the past 
Figure 1 Flowchart showing the screening and enrollment of cases.

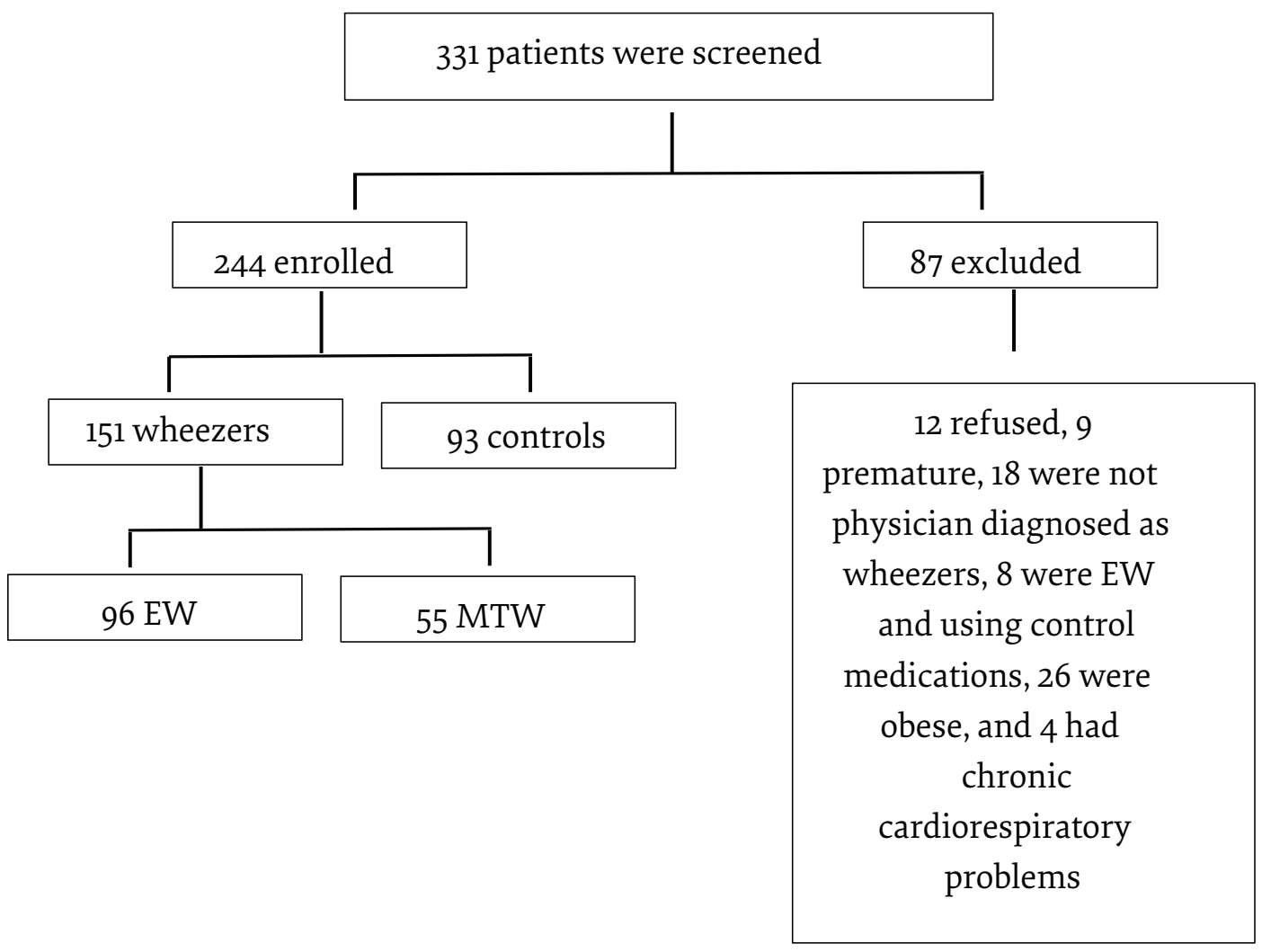

Table 1 Comparison between the wheezers and control groups regarding age, sex, socio-demographic data and serum 25(OH)D level.

\begin{tabular}{|c|c|c|c|}
\hline & Wheezing group (151) & Control group (93) & $\mathbf{P}$ \\
\hline Age (months) & $32(27-40)$ & $32(28.5-41)$ & $0.318^{*}$ \\
\hline Sex (male) & $90(59.6 \%)$ & $44(47.3 \%)$ & $0.065^{* *}$ \\
\hline Consanguinity & $100(66.2 \%)$ & $57(61.3 \%)$ & $0.492^{* *}$ \\
\hline Family history of atopy & $75(49.7 \%)$ & $40(43 \%)$ & $0.356^{* *}$ \\
\hline Other atopies in the case & $64(42.4 \%)$ & $26(28 \%)$ & $0.029^{* *}$ \\
\hline Daycare & $111(73.5 \%)$ & $61(65.6 \%)$ & $0.196^{* *}$ \\
\hline Parental smoking & $63(41.7 \%)$ & $25(26.9 \%)$ & $0.020^{* *}$ \\
\hline \multicolumn{4}{|c|}{ Number of persons in the same house } \\
\hline Up to 5 & $52(34.4 \%)$ & $44(47.3 \%)$ & $0.112^{* *}$ \\
\hline 5-10 & $83(55 \%)$ & $43(46.2 \%)$ & \\
\hline More than 10 & $16(10.6 \%)$ & $6(6.5 \%)$ & \\
\hline \multicolumn{4}{|l|}{ Person to bedroom ratio } \\
\hline 1 & $58(38.4 \%)$ & $51(54.8 \%)$ & $0.024^{* *}$ \\
\hline 2 & $83(55 \%)$ & $40(43 \%)$ & \\
\hline 3 or more & $10(6.6)$ & $2(2.2 \%)$ & \\
\hline Serum 25(OH)D level (ng/ml) & $24.06(15.8-35.62)$ & $28.9(21.6-55.84)$ & $<0.001^{*}$ \\
\hline \multicolumn{4}{|l|}{ Serum 25(OH)D Category } \\
\hline Normal (> $30 \mathrm{ng} / \mathrm{ml}$ ) & $48(31.8 \%)$ & $42(45.2 \%)$ & $0.040^{* *}$ \\
\hline Insufficient (21-29 ng/ml) & $58(38.4 \%)$ & $35(37.6 \%)$ & \\
\hline Deficient (<20 ng/ml) & $45(29.8 \%)$ & $16(17.2 \%)$ & \\
\hline
\end{tabular}

Data are presented as median (IQR) for continuous data and number and percentage for categorical data.

${ }^{*}$ Mann-Whitney U Test,

${ }^{* *}$ Chi-Square test. 
Table 2 Comparison between episodic and multiple trigger wheezers regarding age, sex, sociodemographic data, serum 25(OH)D, ER visits, and hospitalization records

\begin{tabular}{|c|c|c|c|}
\hline & Type of wheer & Theezing group & $\boldsymbol{P}$ \\
\hline & EW (96) & MTW (55) & \\
\hline Age & $32(26-38.75)$ & $33(29-41)$ & $0.123^{*}$ \\
\hline Sex (male) & $61(63.5 \%)$ & $29(52.7 \%)$ & $0.229^{* *}$ \\
\hline Consanguinity & $65(67.7 \%)$ & $35(63.6 \%)$ & $0.721^{* *}$ \\
\hline Family history of atopy & $42(43.8 \%)$ & $33(60 \%)$ & $0.064^{* *}$ \\
\hline Other atopies in the case & $36(37.5 \%)$ & $28(50.9 \%)$ & $0.125^{* *}$ \\
\hline Daycare & $69(71.9 \%)$ & $42(76.4 \%)$ & $0.572^{* *}$ \\
\hline Parental smoking & $34(35.4 \%)$ & $29(52.7 \%)$ & $0.042^{* *}$ \\
\hline Number of persons in the same house & & & \\
\hline Up to 5 & $34(35.4 \%)$ & $18(32.7 \%)$ & $0.945^{* *}$ \\
\hline 5-10 & $52(54.2 \%)$ & $31(65.4 \%)$ & \\
\hline More than 10 & $10(10.4 \%)$ & $6(10.9 \%)$ & \\
\hline Person to bedroom ratio & & & \\
\hline 1 & $41(42.7 \%)$ & $17(30.9 \%)$ & $0.046^{* *}$ \\
\hline 2 & $52(54.2 \%)$ & $31(56.4 \%)$ & \\
\hline 3 or more & $3(3.1 \%)$ & $7(12.7 \%)$ & \\
\hline Serum 25(OH)D level (ng/ml) & $25.67(18.9-39.1)$ & $22.35(15.42-28.15)$ & $0.052^{*}$ \\
\hline Serum 25(OH)D Category & & & \\
\hline Normal (> $30 \mathrm{ng} / \mathrm{ml}$ ) & $33(38.5 \%)$ & $11(20 \%)$ & $0.062^{* *}$ \\
\hline Insufficient (21-29 ng/ml) & $33(34.4 \%)$ & $25(45.5 \%)$ & \\
\hline Deficient $(<20 \mathrm{ng} / \mathrm{ml})$ & $26(27.1 \%)$ & $19(34.5 \%)$ & \\
\hline ER visits in the past 6 months & $50(52.1 \%)$ & $36(65.5 \%)$ & $0.126^{* *}$ \\
\hline ER visits in the past year & $60(62.5 \%)$ & $45(81.8 \%)$ & $0.017^{* *}$ \\
\hline Hospital admission in the past year & $9(9.4 \%)$ & $11(20 \%)$ & $0.081^{* *}$ \\
\hline
\end{tabular}

Data are presented as median (IQR) for continuous data and number and percentage for categorical data.

*Mann-Whitney U Test,

${ }^{* *}$ Chi-Square test.

year $(P=0.017)$ compared to EW. Lower 25(OH)D levels were observed among MTW with more of them in the deficiency category, yet these results did not reach statistical significance as compared to episodic wheezers $(P=0.052)$.

Table 3 shows serum 25(OH)D level according to the season of vitamin D status assessment in the whole cohort and according to the presence or absence of wheezing. Table 4 shows that a decrease in the serum 25(OH)D level was associated with higher risk of wheezing in our series even after adjustment for other variants (model 2, OR
0.965, $\mathrm{P}<0.001)$. Interestingly, low serum 25(OH)D level was an independent risk factor for being a MTW in the cohort of cases (model 2, OR 0.961, P = 0.007) as shown in Table 5 .

When we categorized our cases according to $25(\mathrm{OH})$ D level, Table 6 shows the cases with deficient $25(\mathrm{OH})$ $\mathrm{D}$ had a higher risk of wheezing when compared to the normal group [OR 2.82, $\mathrm{P}=0.013$ ] after adjustment for other variants. The insufficient group had an odds ratio of 1.45 but with no statistical significance $(P=0.278)$.

\begin{tabular}{|c|c|c|c|c|c|}
\hline & & All cases & & tudy groups & \\
\hline & $\mathbf{n}$ & Serum 25(OH)D * & Wheezing group (151) & Control group (93) & $* *$ \\
\hline Summer & 56 & $25.04(20.01-36.87)$ & $22.26(15.67-26.38)$ & $31.91(21.00-46.89)$ & $\mathrm{P} 0.005$ \\
\hline Fall & 66 & $25.48(20.78-41.24)$ & $25.48(20.27-39.37)$ & $26.65(21.16-59.79)$ & P 0.293 \\
\hline Winter & 69 & $22.36(12.25-28.57)$ & $20.76(9.42-26.33)$ & $26.70(19.32-29.02)$ & Р 0.004 \\
\hline Spring & 53 & $43.06(26.73-59.71)$ & $44.59(27.74-56.37)$ & $43.06(24.97-59.91)$ & Р 0.986 \\
\hline
\end{tabular}

Data are presented as median (IQR).

${ }^{*} \mathrm{P}<0.001$ by the Kruskal Wallis test.

**Statistical significance test was done by the Mann-Whitney U-test. 


\begin{tabular}{|c|c|c|c|}
\hline & B & OR $(95 \%$ CI $)$ & $\mathbf{P}$ \\
\hline \multicolumn{4}{|l|}{ Multivariable model $1^{*}$} \\
\hline Serum 25(OH) D levels & -0.029 & $0.971(.957-0.986)$ & $<0.001$ \\
\hline \multicolumn{4}{|l|}{ Multivariable model $2^{* *}$} \\
\hline Serum $25(\mathrm{OH}) \mathrm{D}$ levels & -0.035 & $0.965(.948-0.983)$ & $<0.001$ \\
\hline Male sex & 0.73 & $2.078(1.22-4.3)$ & 0.016 \\
\hline Fall season & 1.132 & $3.1(1.35-7.1)$ & 0.007 \\
\hline Other atopies in the case & 0.83 & $2.29(1.22-4.3)$ & 0.01 \\
\hline Age (months) & -0.03 & 0.97 (0.941-1) & 0.052 \\
\hline
\end{tabular}

${ }^{*}$ Model 1: unadjusted

** Model 2: adjusted for season of serum 25(OH)D measurement, age, sex, day care attendance, parental smoking, other atopies in the cases, family history of atopy, number of persons living in the same house (less than 5, from 5-10 and more than 10), number of children sleeping in the same bedroom (one, two, 3 or more), and consanguinity.

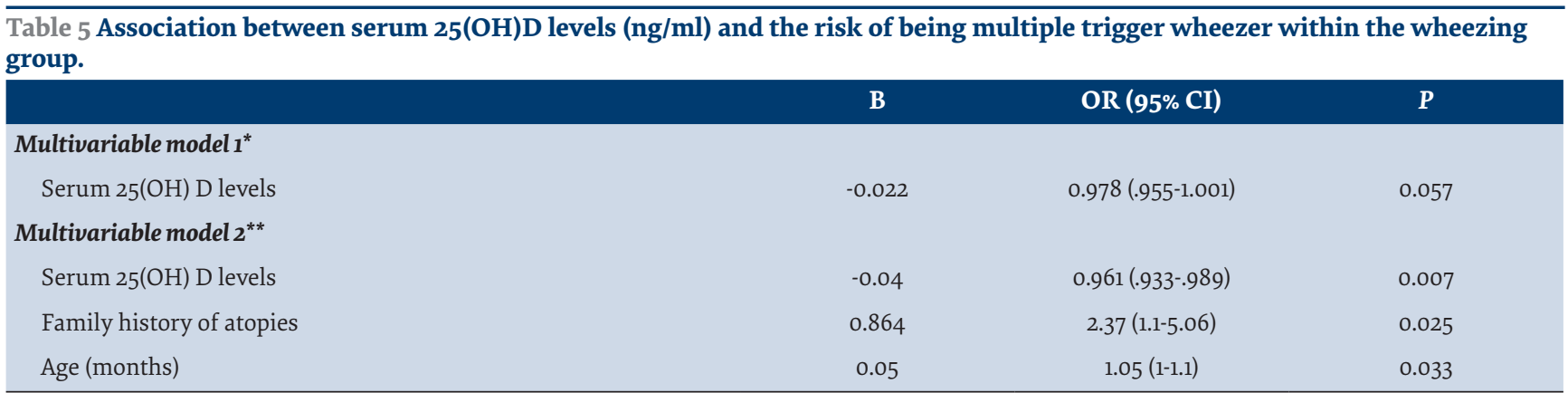

${ }^{*}$ Model 1: unadjusted

${ }^{* *}$ Model 2: adjusted for season of serum 25(OH)D measurement, age, sex, day care attendance, parental smoking, other atopies in the cases, family history of atopy, number of persons living in the same house (less than 5, from 5-10 and more than 10), number of children sleeping in the same bedroom (one, two, 3 or more), and consanguinity.

\begin{tabular}{lcc}
\hline Table 6 Association between serum 25(OH)D categories and the risk of wheezing among the studied cases & $\mathbf{P}$ \\
& OR (95\% CI) & 0.047 \\
Multivariable model * & 1 (reference) & 0.278 \\
Normal $(>30 \mathrm{ng} / \mathrm{ml})$ & $1.45(.742-2.82)$ & 0.013 \\
Insufficient $(21-29 \mathrm{ng} / \mathrm{ml})$ & $2.82(1.24-6.4)$ & \\
Deficient $(<20 \mathrm{ng} / \mathrm{ml})$ &
\end{tabular}

${ }^{*}$ This model shows the association between serum $25(\mathrm{OH}) \mathrm{D}$ categories and the risk of wheezing among the studied cases. The model was adjusted for season of serum $25(\mathrm{OH}) \mathrm{D}$ measurement, age, sex, day care attendance, parental smoking, other atopies in the cases, family history of atopy, number of persons living in the same house (less than 5, from 5-10 and more than 10) and number of children sleeping in the same bedroom (one, two, 3 or more).

\section{Discussion}

The results of the current study revealed significantly more wheezers in the vitamin D deficiency category compared to more controls in the normal category. The regression studies further proved that the decrease in the serum $25(\mathrm{OH}) \mathrm{D}$ level was independently associated with higher risk of wheezing in our series.

Although Uysalol et al. (13) found no significant difference in vitamin $\mathrm{D}$ levels between frequent wheezers and controls (probably due to the younger age of their studied series and their small sample size), several epidemiological studies suggest that low levels of vitamin D during pregnancy and early life are inversely associated with the risk of developing respiratory infections and wheezing in childhood $(19,20)$. Recently in
2016, Prasad et al. (21) reported that each 10ng/ml decrease in vitamin D level is associated with $7.25 \%$ greater odds of wheezing in children less than 3 years of age. In 2014 Stenberg Hammar et al. (22) demonstrated that subnormal levels of vitamin $\mathrm{D}$ are associated with acute wheeze in pre-school children. Additionally, the higher the maternal total vitamin $\mathrm{D}$ intake during pregnancy conferred lower risks for ever wheeze, wheeze in the previous year, and persistent wheeze in 5-year-old children (23).

Although the current study showed lower 25(OH)D levels among MTW with more of them in the deficiency category, yet these results did not reach statistical significance. Nonetheless the regression studies proved that the decrease in the serum 25(OH)D level was independently associated with higher risk of being a MTW. In support of those findings, Uysalol et al. (13) 
reported significantly lower vitamin D in MTW. Vitamin D derangement posting as a possible risk for MTW could be attributed to its potential role in the pathogenesis of atopy (24), or involvement in lung development (25), and not only to the reported increased incidence of respiratory viral infections (26). Data from both animal models and humans support the hypothesis that low vitamin $\mathrm{D}$ is a risk factor for respiratory infection. Vitamin D directly and indirectly induces production of antimicrobial proteins and has other antimicrobial effects $(27,28)$. Additionally, vitamin $\mathrm{D}$ may protect against inflammatory reactions and may be broadly important in regulating chronic lung inflammation (29). Lastly, evidence suggests a role for vitamin D in lung development; vitamin D deficiency in early life may lead to permanent susceptibility and poorer respiratory outcomes that are not atopy related (25).

Significantly more of our series of wheezers gave positive history of atopy and parental smoking with higher person to bedroom ratio, which agrees with Uysalol et al. (13). Similar results were demonstrated when comparing MTW to EW with more hospitalization and ER visits in the previous 6 months and year, yet only the latter reached statistical significance. It is worth noting is that both McNally et al. (30) and Wayse et al. (31) have shown a relationship between lower vitamin D levels and hospitalization.

To our knowledge this the first work that explores the impact of vitamin D deficiency on Kuwaiti wheezers, and although we implemented a strict enrollment criteria and tried to minimize culture and social differences on vitamin D status by assessing only Kuwaiti pre-schoolers, this study has its own limitations. First, the study is cross-sectional and therefore has a number of endemic limitations. Second, not all the cases in the MTW group were on control medications and we did not account for the compliance and drug effect on the frequency and severity of wheezing. Finally, there was no testing for allergen exposure at home, which might influence the occurrence of wheezing and its pattern.

\section{Conclusion}

Derangement in 25(OH)D levels can be linked to wheezing in pre-school Kuwaiti children primarily in the MTW group, which was also more burdened with recurrent ER visits. This emphasizes the importance of consolidating the preventive measures taken to face the deranged vitamin D status, thus eliminating one of the risk factors for wheezing in pre-school age. Cohort studies are needed to clarify the possible link between vitamin D status and the pattern and degree of wheezing for elucidation of the role of vitamin D in the severity of wheezing, and whether such cases would benefit from vitamin D supplementation.

Funding: None.

Competing interests: None declared.

\section{Statut de la 25-hydroxyvitamine D sérique et respiration sifflante chez les enfants d'âge préscolaire, Koweït Résumé}

Contexte : On reconnaît de plus en plus les rôles extra-squelettiques critiques joués par la vitamine $\mathrm{D}$, y compris dans les maladies pulmonaires.

Objectifs : La présente étude a été réalisée pour explorer le rôle possible de la vitamine D dans l'apparition de la respiration sifflante chez des enfants koweïtiens d'âge préscolaire.

Méthodes : Sur les 244 enfants de l'hôpital Al-Adan, 151 cas ont été inscrits comme siffleurs et les autres ont servi de témoins. Les siffleurs ont été subdivisés en siffleurs épisodiques et siffleurs récurrents de causes multiples. Les antécédents détaillés des crises de respiration sifflante, les hospitalisations antérieures et les admissions aux soins intensifs ont été consignés, ainsi que leurs taux de 25-hydroxyvitamine D sériques [25(OH)D].

Résultats : Le 25(OH)D sérique était significativement plus faible dans le groupe de respiration sifflante, et sa diminution était un facteur de risque de respiration sifflante. De plus, le taux de 25(OH)D sérique n'était pas significativement différent entre les siffleurs épisodiques et les siffleurs récurrents de causes multiples; néanmoins, son bas niveau pourrait être lié à la respiration sifflante récurrente de causes multiples.

Conclusions : La carence en vitamine D augmente le risque de respiration sifflante chez les enfants d'âge préscolaire au Koweït. Un lien possible entre un faible taux de 25(OH)D sérique et la respiration sifflante récurrente de causes multiples pourrait mettre en évidence un rôle spécifique de la vitamine $\mathrm{D}$ en lien avec l'atopie. La prévention et la prise en charge rapide de la carence en vitamine $\mathrm{D}$ devraient être envisagées chez les nourrissons et les enfants dont la respiration est sifflante. 


\section{حالة مصل هץ ه-هيدرو كسي فيتامين دوصفير الصدر لدى الأطفال ما قبل سن المدرسة، الكويت}

$$
\text { علاء محمد عبد القادر، مي فؤاد نصار }
$$

الخلفية: يتزايد الاعتراف بالدور الإضافي البالغ الأهمية لفيتامين د إلى جانب الهيكل العظمي، بها في ذلك علاج أمر اض الرئة.

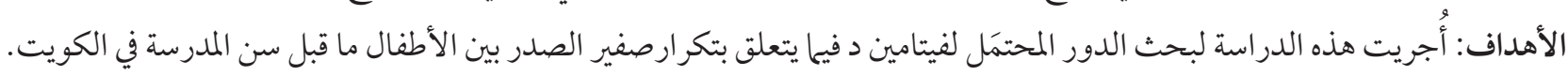

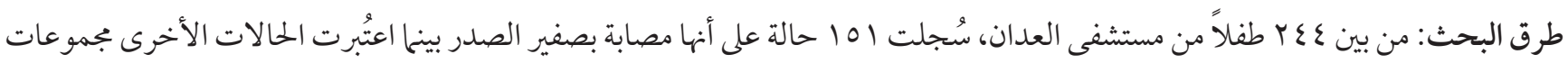

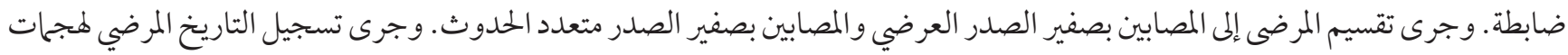

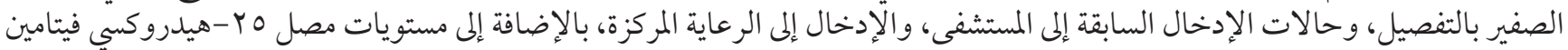
د

النتائج: كان مستوى مصل ه O OH)D)Y منخفضًا بشكل كبير في مجموعة المصابين بصفير الصدر، وكان انخفاضه أحد عو امل الخطر المؤدية للإصابة

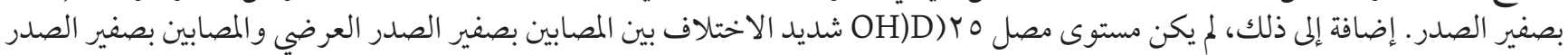

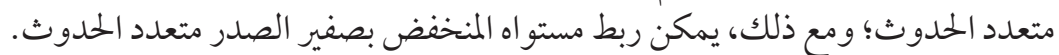

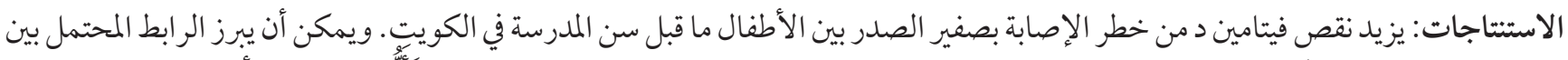

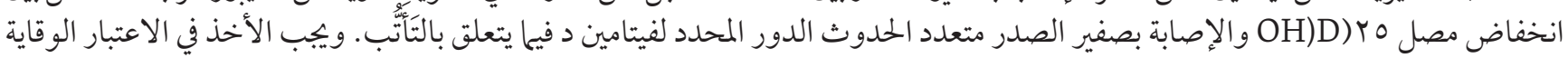

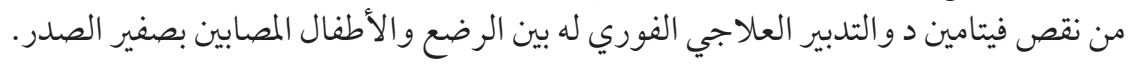

\section{References}

1. Bikle D. Nonclassic actions of vitamin D. J Clin Endocrinol Metab. 2009;94(1):26-34. http://dx.doi.org/10.1210/jc.2008-1454

2. Gupta D, Vashi PG, Trukova K, Lis CG, Lammersfeld CA. Prevalence of serum vitamin D deficiency and insufficiency in cancer: review of the epidemiological literature. Exp Ther Med. 2011;2(2):181-93. http://dx.doi.org/10.3892/etm.2011.205

3. Vitamin D. fact sheet for health professionals. National Institutes of Health website. (https://ods.od.nih.gov/factsheets/VitaminD-HealthProfessional/, accessed 28 June, 2017).

4. Fields J, Trivedi NJ, Horton E, Mechanick JI; Fields J1. Trivedi NJ, Horton E, Mechanick JI. Vitamin D in the Persian Gulf: integrative physiology and socioeconomic factors. Curr Osteoporos Rep. 2011;9(4):243-50. http://dx.doi.org/10.1007/s11914-011-0071-2

5. Lubani MM, al-Shab TS, al-Saleh QA, Sharda DC, Quattawi SA, Ahmed SA, et al. Vitamin-D-deficiency rickets in Kuwait: the prevalence of a preventable disease. Ann Trop Paediatr. 1989;9(3):134-9. http://dx.doi.org/10.1080/02724936.1989.11748616

6. Al-Shawi AN. Nutrient intakes of university women in Kuwait. J R Soc Health. 1992;112(3):114-8. http://dx.doi. org/10.1177/146642409211200302

7. Nassar MF, Abdel Kader AM, Al Refaee FA, Al Dahfiri SS. Pattern of beverage Intake and milk and dairy product sufficiency among high school students in Kuwait. East Mediterr Health J. 2014;17:738-44. http://dx.doi.org/10.26719/2014.20.11.738

8. Al-Refaee FA, Nassar MF. Vitamin D supplementation for infants in Kuwait: physicians' perspectives. J Bahrain Med Soc. 2013;24:111-4.

9. Molla AM, Al Badawi M, Hammoud MS, Molla AM, Shukkur M, Thalib L, et al. Vitamin D status of mothers and their neonates in Kuwait. Pediatr Int. 2005;47(6):649-52. http://dx.doi.org/10.1111/j.1442-200x.2005.02141.x

10. Alyahya K, Lee WT, Al-Mazidi Z, Morgan J, Lanham-New S. Risk factors of low vitamin D status in adolescent females in Kuwait: implications for high peak bone mass attainment. Arch Osteoporos. 2014;9(1):178. http://dx.doi.org/10.1007/s11657-014-0178-z

11. Holick MF. Vitamin D deficiency. N Engl J Med. 2007;357(3):266-81. http://dx.doi.org/10.1056/NEJMra070553

12. Foong RE, Zosky GR, Vitamin D. Deficiency and the lung: disease initiator or disease modifier? Nutrients. 2013;5(8):2880-900. http://dx.doi.org/10.3390/nu5082880

13. Uysalol M, Uysalol EP, Yilmaz Y, Parlakgul G, Ozden TA, Ertem HV, et al. Serum level of vitamin D and trace elements in children with recurrent wheezing: a cross-sectional study. BMC Pediatr. 2014;16(14):270.

14. Behbehani NA, Abal A, Syabbalo NC, Azeem AA, Shareef E, Al-Momen J. Prevalence of asthma, allergic rhinitis, and eczema in 13to 14-year-old children in Kuwait: an ISAAC study. International Study of Asthma and Allergies in Childhood. Ann Allergy Asthma Immunol. 2000;85(1):58-63. http://dx.doi.org/10.1016/S1081-1206(10)62435-0

15. Mallol J, García-Marcos L, Solé D, Brand P, EISL Study Group. International prevalence of recurrent wheezing during the first year of life: variability, treatment patterns and use of health resources. Thorax. 2010;65(11):1004-9. http://dx.doi.org/10.1136/ thx.2009.115188

16. Ducharme FM, Tse SM, Chauhan B. Diagnosis, management, and prognosis of preschool wheeze. Lancet. 2014;383(9928):1593604. http://dx.doi.org/10.1016/So140-6736(14)60615-2 
17. Brand PL, Baraldi E, Bisgaard H, Boner AL, Castro-Rodriguez JA, Custovic A, et al. Definition, assessment and treatment of wheezing disorders in preschool children: an evidence-based approach. Eur Respir J. 2008;32(4):1096-110. http://dx.doi. org/10.1183/09031936.00002108

18. Holick MF, Binkley NC, Bischoff-Ferrari HA, Gordon CM, Hanley DA, Heaney RP, et al. Evaluation, treatment, and prevention of vitamin D deficiency: an Endocrine Society clinical practice guideline. J Clin Endocrinol Metab. 2011;96(7):1911-30. http://dx.doi. org/10.1210/jc.2011-0385

19. Camargo CA Jr, Ingham T, Wickens K, Thadhani R, Silvers KM, Epton MJ, et al. Cord-blood 25-hydroxyvitamin D levels and risk of respiratory infection, wheezing, and asthma. Pediatrics. 2011;127(1):e180-7. http://dx.doi.org/10.1542/peds.2010-0442

20. Comberiati P, Tsabouri S, Piacentini GL, Moser S, Minniti F, Peroni DG. Is vitamin D deficiency correlated with childhood wheezing and asthma? Front Biosci (Elite Ed). 2014;1(6):31-9.

21. Prasad S, Rana RK, Sheth R, Mauskar AV. [REMOVED HYPERLINK FIELD]. A Hospital Based Study to Establish the Correlation between Recurrent Wheeze and Vitamin D Deficiency Among Children of Age Group Less than 3 Years in Indian Scenario. J Clin Diagn Res. 2016;10:SC18-21.

22. Stenberg Hammar K, Hedlin G, Konradsen JR, Nordlund B, Kull I, Giske CG, et al. Subnormal levels of vitamin D are associated with acute wheeze in young children. Acta Paediatr. 2014;103(8):856-61. http://dx.doi.org/10.1111/apa.12666

23. Devereux G, Litonjua AA, Turner SW, Craig LC, McNeill G, Martindale S, et al. Maternal vitamin D intake during pregnancy and early childhood wheezing. Am J Clin Nutr. 2007;85(3):853-9. http://dx.doi.org/10.1093/ajcn/85.3.853

24. Keet CA, McCormack MC, Peng RD, Matsui EC. Age- and atopy-dependent effects of vitamin D on wheeze and asthma. Allergy Clin Immunol. 2011;128(2):414-6.e5. http://dx.doi.org/10.1016/j.jaci.2011.06.011

25. Zosky GR, Berry LJ, Elliot JG, James AL, Gorman S, Hart PH. Deficiency Causes Deficits in Lung Function and Alters Lung Structure. Am J Respir Crit Care Med. 2011;183(10):1336-43. http://dx.doi.org/10.1164/rccm.201010-1596OC

26. Jartti T, Ruuskanen O, Mansbach JM, Vuorinen T, Camargo CA Jr. Low serum 25-hydroxyvitamin D levels are associated with increased risk of viral coinfections in wheezing children. J Allergy Clin Immunol. 2010;126(5):1074.e4. http://dx.doi.org/10.1016/j. jaci.2010.09.004

27. Taylor CE, Camargo CA Jr. Impact of micronutrients on respiratory infections. Nutr Rev. 2011;69(5):259-69. http://dx.doi. org/10.1111/j.1753-4887.2011.00386.x

28. Herr C, Greulich T, Koczulla RA, Meyer S, Zakharkina T, Branscheidt M, et al. The role of vitamin D in pulmonary disease: COPD, asthma, infection, and cancer. Respir Res. 2011;18;12:31.

29. Sandhu MS, Casale TB. The role of vitamin D in asthma. Ann Allergy Asthma Immunol. 2010 Sep;105(3):191-9; quiz 200-2, 217.

30. McNally JD, Leis K, Matheson LA, Karuananyake C, Sankaran K, Rosenberg AM. Vitamin D deficiency in young children with severe acute lower respiratory infection. Pediatr Pulmonol. 2009;44(10):981-8. http://dx.doi.org/10.1002/ppul.21089

31. Wayse V, Yousafzai A, Mogale K, Filteau S. Association of subclinical vitamin D deficiency with severe acute lower respiratory infection in Indian children under 5 y. Eur J Clin Nutr. 2004;58:563-7. 